\title{
PAUL MULDOON EM TRADUÇÃO
}

\author{
PAUL MULDOON IN TRANSLATION
}

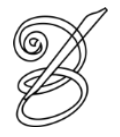 \\ Traduzido por: \\ Guilherme BERNARDES* \\ Universidade Federal do Paraná \\ Curitiba, Paraná, Brasil
}

\begin{abstract}
Resumo: Paul Muldoon (1951 - ) é um poeta norte-irlandês de origem católica nascido em Portdown, condado de Armagh. Integrou junto a Seamus Heaney, Michael Longley e Ciaran Carson, dentre outros, o chamado Belfast Group, organizado por Philip Hobsbaum. Publicou seu primeiro livro, New Weather, em 1973. Desde então, já publicou mais doze coletâneas de poemas, sendo a mais recente Frolic and Detour, em 2019. Além disso, já publicou literatura infantil, libretos de ópera, coletâneas de letras de música e peças de teatro. Já foi premiado com o T.S. Eliot Prize for Poetry por The Annals of Chile (1994) e o Pulitzer Prize for Poetry por Moy Sand and Gravel (2002). Mudou-se para os Estados Unidos em 1987, onde foi professor do curso de escrita criativa na Universidade de Princeton até 2017 e foi, até 2016, editor de poesia da revista The New Yorker. As traduções a seguir integram o apêndice da dissertação "Uma Camisa de Força para Houdini: Paul Muldoon, Forma Fixa e Tradução", defendida em fevereiro de 2020 na UFPR.
\end{abstract}

Palavras-chave: Paul Muldoon. Tradução. Poesia Irlandesa. Forma Fixa. Poesia Contemporânea.

Abstract: Paul Muldoon (1951 - ) is a Northern-Irish poet from a catholic background who was born in Portdown, County Armagh. Along with Seamus Heaney, Michael Longley and Ciaran Carson, among others, he was part of the so called Belfast Group, organized by Philip Hobsbaum. His first book, New Weather, was published in 1973. Since then, he has published twelve other books of poems, the most recent being Frolic and Detour, in 2019. Besides that, he has already published children's literature, opera libretti, collections of rock n ' roll lyrics and plays. He has been awarded the T.S. Eliot Prize for Poetry for The Annals of Chile (1994) and the Pulitzer Prize for poetry for Moy Sand and Gravel (2002). He moved to the United States in 1987, where he was an associate professor of the Creative Writing Program at Princeton University until 2017 and also, until 2016, poetry editor for The New Yorker magazine. The following translations are part of the appendix of the thesis "Uma Camisa de Força para Houdini: Paul Muldoon, Forma Fixa e Tradução", defended at UFPR in February 2020.

Keywords: Paul Muldoon. Translation. Irish Poetry. Fixed Form. Contemporary Poetry.

RECEBIDO EM: 25 de novembro de 2019

ACEITO EM: 26 de fevereiro 2020

PUBLICADO EM: março 2020 


\section{KATE WHISKEY}

I kept the whiskey in the caves

Well up in the hills. It was never safe

To have it about the houses,

Always crawling with excise and police.

The people could still get the stuff

As often as they liked, and easily enough,

For those were still the days

When making whiskey broke nobody's laws.

Selling it, though, was as grave

An offence as teaching those people to love,

Fathers and husbands and boys.

Water rushed through my caves with a noise

To tell me how I should always live.

I sold the water, the whiskey I would give.

\section{KATE WHISKEY}

Deixava o uísque nas cavernas

Desse morro. Era arriscado ter num

Cômodo qualquer da casa,

Com tanto suborno, polícia e taxas.

Ainda dava pra arranjar aquilo

O quanto quisesse, era tranquilo

Porque ainda, naquela época,

Não era contra a lei ser uma fábrica.

Vender, porém, era ofensa maior

Que ensinar para eles o amor,

Eram pais e maridos e filhos.

Na caverna a água faz barulho E me relembra essa lição tão grande:

Vendia só água, o uísque era um brinde.

\section{THE MIXED MARRIAGE}

My father was a servant-boy.

When he left school at eight or nine

He took up billhook and loy

To win the ground he would never own.

My mother was the school-mistress,

The world of Castor and Pollux.

There were twins in her own class.

She could never tell which was which.

She had read one volume of Proust, He knew the cure for farcy.

I flitted between a hole in the hedge

And a room in the Latin Quarter.

When she had cleared the supper-table

She opened The Acts of the Apostles, Aesop's Fables, Gulliver's Travels.

Then my mother went on upstairs

And my father further dimmed the light

To get back to hunting with ferrets

Or the factions of the faction-fights,

The Ribbon Boys, the Caravats.

\section{O MATRIMÔNIO MISTO}

Meu pai foi menino-peão.

Saiu da escola aos oito ou nove

Pra com foice e enxada na mão

Cuidar de uma terra sem seu nome.

Minha mãe ensinava, conforme o

Mundo de Castor e Pólux.

Havia gêmeos em sua turma.

Nunca soube qual era qual.

Ela tinha lido um pouco de Proust,

Ele sabia a cura do mormo.

Eu variava entre os arbustos

E um quarto no Quartier Latin.

Quando recolhia a ceia,

Ela abria Os Atos dos Apóstolos,

Fábulas de Esopo, Viagens de Gulliver.

Então minha mãe subia

E meu pai deixava a luz exígua

Pra, com os furões, voltar à caça

Ou às mesmas facções das brigas,

Os Ribbon Boys, os Caravats. 


\section{THE BOUNDARY COMMISSION}

You remember that village where the border ran

Down the middle of the street,

With the butcher and baker in different states?

Today he remarked how a shower of rain

Had stopped so cleanly across Golightly's lane

It might have been a wall of glass

That had toppled over. He stood there, for ages,

To wonder which side, if any, he should be on.

\section{WHY BROWNLEE LEFT}

Why Brownlee left, and where he went Is a mystery even now.

For if a man should have been content It was him; two acres of barley, One of potatoes, four bullocks, A milker, a slated farmhouse.

He was last seen going out to plough

On a March morning, bright and early.

By noon Brownlee was famous;

They had found all abandoned, with The last rig unbroken, his pair of black Horses, like man and wife, Shifting their weight from foot to Foot, and gazing into the future.

\section{THE SIGHTSEERS}

My father and mother, my brother and sister and I, with uncle Pat, our dour best-loved uncle,

had set out that Sunday afternoon in July in his broken-down Ford

not to visit some graveyard-one died of shingles, one of fever, another's knees turned to jellybut the brand-new roundabout at Ballygawley,

\section{A COMISSÃO DE FRONTEIRA}

Lembra do jeito que a fronteira cortava a rua

Daquela vila, bem no centro, Açougue num estado, padaria em outro?

Hoje ele lembrou que uma pancada de chuva

Dividiu a ruazinha Golightly em duas,

Como se houvesse um muro de vidro Ali caído. Ficou lá por eras, como pedra,

Só pensando se alguma delas era a sua.

\section{POR QUE BROWNLEE SE FOI}

Por que Brownlee se foi, e a qual país, É um mistério até agora.

Porque se alguém devia estar feliz

Era ele; dois acres de cevada,

Um de batata, quatro touros, Uma leiteira, casa na fazenda. Foi visto indo arar antes de ir embora Numa manhã de março iluminada.

Ao meio-dia Brownlee era lenda; Acharam lá, abandonados, Presos por um fio de couro, os Cavalos pretos, como se casados. Alternando o peso de pé em Pé, admirando tudo que vem.

\section{OS TURISTAS}

Meu pai, minha mãe, meu irmão, minha irmã e eu, com tio Pat, o mais gentil dos nossos tios, saímos de tarde, num domingo de julho, no seu Ford aos pedaços

não pra ir no cemitério - um morreu de zóster,

um foi de febre, outro detonou o joelho mas na rotatória nova em Ballygawley, primeira de Mid-Ulster. 
the first in mid-Ulster.

Uncle Pat was telling us how the B-Specials had stopped him one night somewhere near Ballygawley and smashed his bicycle

and made him sing the Sash and curse the Pope of Rome.

They held a pistol so hard against his forehead

there was still the mark of an $\mathrm{O}$ when he got home.

\section{SOMETHING ELSE}

When your lobster was lifted out of the tank to be weighed

I thought of woad,

of madders, of fugitive, indigo inks,

of how Nerval

292 was given to promenade

a lobster on a gossamer thread, how, when a decent interval

had passed

(son front rouge encor du baiser de la reine) and his hopes of Adrienne

proved false, he hanged himself from a lamp-post

with a length of chain, which made me think of something else, then something else again.
Tio Pat contou que os B-Specials, quase manhã, mandaram parar perto de Ballygawley quebraram a bicicleta e o

fizeram cantar a Sash e xingar o Papa. Pressionaram a pistola com tanta força que em sua testa ainda havia um $\mathrm{O}$, chegando em casa.

\section{OUTRA COISA}

Quando, pra pesar, tiraram tua lagosta do tonel pensei na pastel, na granza, em pigmentos celestes,

em como Nerval passeava, às vezes, uma lagosta num fio de gaze, como, passado um intervalo,

pouco depois, (son front rouge encor du baiser de la reine) e a esperança em Adrienne

virou recusa, se enforcou num poste de luz com uma corrente, e eu pensei, no susto,

em outra coisa, e outra coisa também.

\section{AFTERMATH}

"Let us now drink," I imagine patriot cry to patriot

after they've shot

a neighbor in his own aftermath, who hangs still between two sheaves

like Christ between two tousle-headed thieves, his body wired up to the moon, as like as not.

\section{OUTONADA}

\section{I}

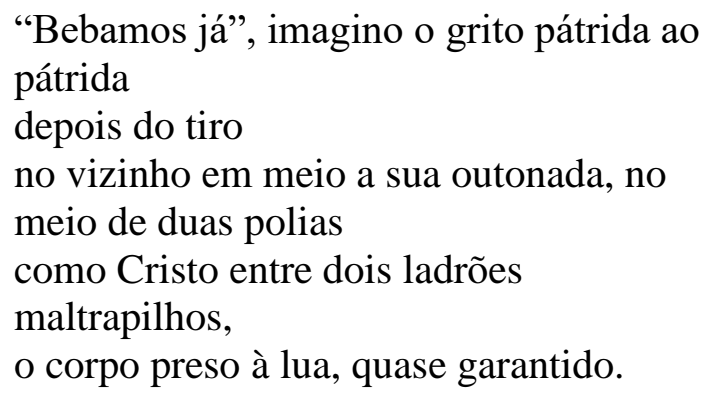


To the memory of another left to rot near some remote beauty spot, the skin of his right arm rolled up like a shirtsleeve, let us now drink.

III

Only a few nights ago, it seems, they set fire to a big house and it got so preternaturally hot we knew there would be no reprieve till the swallows' nests under the eaves had been baked into these exquisitely glazed little pots from which, my love, let us now drink.
À memória de outro abandonado e desistido perto de alguma beleza contida, a manga arregaçada do braço - sua pele -, bebamos já.

\section{III}

Há poucas noites, parece, tacaram fogo numa casa grande e tudo esquentou como um feitiço que não dava mais pra pular até que os ninhos de andorinha nos pilares cozinhassem de virar panelinhas esquisitas, das

quais, meu amor, bebamos já.

\section{REFERÊNCIA}

MULDOON, Paul. Poems 1968-1998. Nova Iorque: Farrar, Straus and Giroux, 2001.

\footnotetext{
* Guilherme BERNARDES - Graduado em Letras - Português e Latim com ênfase em Estudos da Tradução (2017) pela Universidade Federal do Paraná. Mestrando em Letras pela mesma instituição. Universidade Federal do Paraná, Setor de Ciências Humanas, Programa de Pós-Graduação em Letras. Curitiba, Paraná, Brasil.

Currículo acadêmico: http://lattes.cnpq.br/6502159348859643

ORCID: http://orcid.org/0000-0001-7510-0266

E-mail: obsolescencias@gmail.com
} 